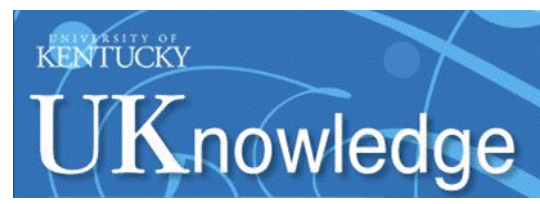

Kentucky Law Journal

Volume 15 | Issue 1

Article 1

1926

\title{
The Law of Cooperative Marketing Associations
}

Aaron Sapiro

Follow this and additional works at: https://uknowledge.uky.edu/klj

Part of the Agriculture Law Commons

Right click to open a feedback form in a new tab to let us know how this document benefits you.

\section{Recommended Citation}

Sapiro, Aaron (1926) "The Law of Cooperative Marketing Associations," Kentucky Law Journal: Vol. 15: Iss. 1, Article 1.

Available at: https://uknowledge.uky.edu/klj/vol15/iss1/1

This Article is brought to you for free and open access by the Law Journals at UKnowledge. It has been accepted for inclusion in Kentucky Law Journal by an authorized editor of UKnowledge. For more information, please contact UKnowledge@lsv.uky.edu. 


\section{KENTUCKY LAW JOURNAL}

\begin{tabular}{lll}
\hline \hline Volume XV. NOVEMBER, 1926. & Number 1. \\
\hline
\end{tabular}

\section{THE LAW OF COOPERATIVE MARKETING ASSO- CIATIONS}

Ten years ago, the law that affected Cooperative Marketing Association was somewhat chaotic. In a few states, such as Kentucky, Indiana, Alabama, there were a series of sympathetic court decisions under which certain types of Cooperatives could thrive.

In other states there was a distinct antagonism toward Cooperative Marketing activities. In Iowa, the famous cases, Reeves v. Decorah Society, 140 N. W. 844, and Ludowese v. Farmers' Cooperative Co., 145 N. W. 475, announced that contracts between Cooperative Associations and their own members binding the members to deliver their specified products to the association and assessing liquidated damages in the event of a breach, were invalid and contrary to sound public policy.

In Colorado, the case of Burns v. Wray, 176 Pac. 487, announced a similar doctrine and paralyzed the development of effective Cooperatives in the Mountain States.

These decisions had much to do with the growth of Cooperative activity among the farms into purely local organizations, excellent in their way but wholly incapable of solving the fundamental problems of marketing farm products.

Small cooperative Associations berame common for making butter or cheese, as in Minnesota or Wisconsin; but they failed to federate for marketing purposes on any large scale.

Local grain groups built elevators to act as a local commission house, owned by the farmers and distributing patronage dividends from their profits, when there were any.

For years the Middle West was cramped into the local style by both economic and legal binders-and the system seemed fixed forever by the limitations of legal rights as announced by the courts. 
In the far West, however, a new interpretation of farmers' marketing associations had been announced. The fruit growers of Califormia had been experimenting with various types of Cooperation and had failed so often and renewed the attempts after studies of their failures that they were bound to find the light.

Without realizing that they were discovering a principle, these fruit growers had organized local associations to pack and standardize fruit; and then these associations had federated into an exchange for the actual marketing of the fruit. The growers handled through their organization only related fruits, such as oranges and lemons. With the raisin growers, there were no locals but only a single central association which packed raisins at the most convenient points-not at each local centerand therefore had no need for locals.

This was organization by the commodity in contrast to organization by locality. They thought in terms of the commodity only-of merchandising the commodity just as great soap manufacturers or typewriter makers merchandise a single commodity.

The farmers in the far West had somehow stumbled on the realization that they were not helpless under the sacred law of the economists, the law of supply and demand. They found the movable factors in that law-time and place; and they learned that the most important element in making price was not the mere statistical position of supply or demand but the ability to adjust supply to demand at any given time in any given place.

This adjustment could not be made by a single farmer; nor by a local association or even a small group of locals. But it could be made by farmers who could control and be certain of the control of a large percentage of the commodity and could help guide the flow of that commodity into the markets of the world.

So the commodity idea was developed and finally announced. In its train it drew along the necessity for a binding contract. If packing houses were to be erected there had to be a certainty of paying for them and of maintaining them. If commodity cooperatives were to advertise and sell fruit, often in advance of delivery by the farmers, they had to be sure that the farmers would deliver. 
So the binding contract developed; and obligations and rights of various kinds grew along with the contracts.

The inevitable happened. Law began to conform slowly to the economic advance. The farmers had found a definite trend; and law put flesh on its dry bones and grew again in the same measure.

These commodity associations were large and powerful. Sometimes they were the very largest factors in the entire industry, such as the Associated Raisin Company, the California Fruit Growers' Exchange, the California Walnut Growers' Exchange. They were so important that some could actually name the price of the commodity, just as the great manufacturers of other wares make and change their prices from time to time. The Walnut Growers' Exchange dominated the market for domestic walnuts; named the prices for graded walnuts. Of course, these exchanges tried to exercise their powers wisely. Good merchants in any line do not gouge the public but fix prices high enough to make a profit and low enough to keep down any intensive increases in production.

Among good merchants profits must justify their staying in business but must discourage others from abandoning their orvn activities to get into the apparently favored field.

Nevertheless, all men are not good merchants; and the public has not put its faith in the wisdom of good merchandising alone. The public demanded and secured strong anti-trust legislation, both Federal and State, to curb monopolies and prevent price-making abuses and to throttle organizations or combinations formed for the purpose of bettering prices or restraining trade.

These commodity organizations were combinations of farmers organized frankly to minimize speculation; to stabilize markets; to get more money for the farmers without necessarily increasing price to the consumer. The history of the California Fruit Growers' Exchange has demonstrated that such a commodity organization could and did increase the return to the farmer more than $300 \%$ and, in the same period, actually decreased the average cost of oranges to the retail trade and the consumer. 
But in other instances, an increase to the farmer has coincided with an increase, slight or large, to the consumer, notably in the prices of raisins in the period from 1919 to 1922.

This power to affect prices through commodity organizations, whenever they came into control by contract over any large proportion of a commodity, made conflicts inevitable. The great distributors, the powerful packers, began to fight against these farmer organizations. They tried to get actions started for violation of anti-trust laws. They worked, in a far more skillful way, to break up the associations by persuading members to break their contracts, by dissatisfying them with the cooperatives, by open warfare or secret, depending on the natural tendencies of the antagonists.

It was soon found that the easiest way to destroy a cooperative was to spread tales about the managers and their policies. Cooperatives of the right type are exactly like democracies-and they have the faults as well as the virtues of democracies.

Many members feel that they can run the cooperative as well as a trained manager and at much less expense, just as snany citizens feel themselves eminently fitted to instruct the nation on all sorts of political issues without any training or perceptible study whatsoever.

There is always a fertile field for rumors in a cooperativepreferably ugly, personal rumors. They go fast and they grow in the going. Soon the cooperative spirit is frozen, just as depositors lose faith and start runs on the bank, when rumors fly about on black wings.

The next easiest way to destroy a cooperative is to pay good prices to the non-cooperator and to buy from the cooperative only when the outside products are all exhausted.

Then if there is the least carryover, the cooperative must carry it; and on that part of the crop it may distribute to the grower-members only what it has borrowed thereon-but no final sale-price.

Thus the outsider often gets a better return for his crop than the cooperative member; and he boasts of it to the cooperator to indicate his superior marketing wisdom. He does not realize that he has sold himself along with his prunes or his tobacco and he does not seem to see that, were it not for the 
existence of the cooperative, neither he nor the cooperators could have received the prices they finally did get.

This causes bitter dissatisfaction; and frequently the impatient member wants to become an outsider and he chafes at his contract.

Then a few dealers sometimes are bold enough to suggest to members that they break their contracts and sell the product to the dealers, under an agreement by which the dealer will pay more than the association price, whatever it may be; and protect the member from any cost or loss by reason of actions against him for breach of contract.

These and other reasons led to much litigation, within and by the cooperatives. Many members would become dissatisfied for justifable reasons and then, without legal justification, break their contracts, before attempting to remedy the situation by changes of management or otherwise.

The legal background was confused even in states where the judicial trend seemed favorable to farmer organizations. For example, it was soon recognized that liquidated damages would be inadequate where a grower agreed to deliver all the eggs produced by his hens and the cooperative association, relying on this agreement, sold a reasonable quantity of eggs for future delivery. Equitable relief would be the only satisfactory remedy to enjoin the grower from selling to any outside commission merchant and to compel him to give specific performance of his contract. Yet in California, where this idea was first developed, we were unsuccessful in establishing the doctrine because of a statutory code provision which appeared to limit these associations to liquidated damages.

Under the stress of economic pressure and legal confusion, it seemed best to try to anticipate and settle most of the legal difficulties by' statute and to fix the trend of legislation which would in turn fix the trend of court decisions.

In Federal Legislation, the farmer groups desired the same kind of exemption from anti-trust laws that was generally accorded to labor unions. Section 6 of the Clayton Act grants a kind of exemption and seems to indicate that a cooperative association may be organized, without capital stock and without any aim of profit for itself, and be exempt from attack as to its form of organization, its existence as a combination of growers. 
But there is apparently no exemption here from any abuse of power by such an organization, even where its form of organization is held proper.

Then the Capper-Volstead Act (1922) made the exemption far more specific and indicated bluntly that these Cooperative Associations could fix prices and might sometimes try to abuse that power. If so, a remedy was set forth under which complaint may be made and the Secretary of Agriculture may order the price reduced; and, if the Association fails to obey, he may cause its dissolution.

This is the only instance in our legislative history, where any industry not public in character and not acting under a war-crisis, voluntarily suggested and accepted against itself the right of any governmental officer to control and curb its pricemaking power.

There are also recorded certain exemptions from income taxes and other small bits of legislation, all tending to show a desire on the part of the Federal Government to aid and encourage cooperative marketing. The last bit of legislation was the Haugen Bill (1926), which authorized the Secretary of Agriculture to set up a Bureau of Cooperative Marketing within the Department and to earry on rather extended activities as to investigations and conferences and dissemination of information.

Generally speaking, Federal Legislation has been exemptive in character, shielding the Farmers' Associations from part of the anti-trust laws and from income taxes-and by these pronouncements, the Federal Government has indicated a clear policy of encourngement for cooperative marketing.

It is significant to note that, in these days when combinations of industrial units seem to be so desirable economically, the farmers are the only great producers of actual commodities who may form the tightest type of combination, for both domestic and foreign trade, without interference of law by reason of the form or fact of organization.

There is a reason to justify this; the peculiar charaster of agricultural industry is individual in production whereas other industries are characterized by group production.

If a price is forced out of line in an industry built on individual production, every man extends his acreage or goes newly 
into that commodity and inevitable overproduction follows and swamps the industry. Exactly this did happen with the great Raisin Growers' Company in the last four years. Thus, there is an automatic protection to the public and a constant threat to the growers themselves if they abuse their power through organization.

With group production industries there is no such automatic protection. If a steel trust raises the price of steel rails beyond conscience, very few can flock into the business. Too much capital is there required. Therefore there is regulation by law in all group production industries.

Thus Federal legislation cleared the way for effective organization of commodity cooperatives.

Then the attempt was made to codify the legal experiences of cooperative associations, to prepare a standard law which would define the powers of cooperatives; their method of organization; internal control; limitations of membership; types of contracts they might make; enforcement of such contracts with both legal and equitable remedies; protection of such contracts by providing for penalties for those who urge members to breals them; exemption from local anti-trust statutes and certain local taxes; extension of these rights by comity to cooperatives organized under similar laws in other states.

This was a deliberate attempt to settle by statute matters which had been argued for years before many courts, with varying primary decisions and some variance even in appellate courts.

The act was first adopted in Texas in 1921. But the best form of the act is the Bingham Cooperative Marketing Act of Kentucky, aclopted early in 1922. This act contains the announcement of public policy and, among other things, sets forth in Section 5 the reason for the encouragement of farmer combinations because of the peculiar nature of the industry.

Section 1 of the Bingham Act reads:

"Declaration of Policy.

(a) In order to promote, foster and encourage the intelligent and orderly marketing of agricultural products through cooperation; and to eliminate speculation and waste; and to make the distribution 
of agricultural products between producer and consumer as direct as can be efficiently done; and to stabilize the marketing of agricultural products, this Act is passed."

\section{Section 5 reads :}

\section{"Preliminary Investigation.}

Every group of persons contemplating the organization of an association under this act is urged to communicate with the Dean of the College of Agriculture of the University of Kentucky, who will inform them whateve $\vec{r}$ a survey of the marketing conditions affecting the commodities proposed to be handled may indicate regarding probable success.

It is here recognized that agriculture is characterized by individual production in contrast to the group or factory system that characterizes other forms of industrial production; and that the ordinary form of corporate organization permits industrial groups to combine for the purpose of group production and the ensuing group marketing and that the public has an interest in permitting farmers to bring their industry to the high degree of efficiency and merchandising skill evidenced in the manufacturing industries; and that the public interest urgently needs to prevent the migration from the farm to the city in order to keep up farm production and to preserve the agricultural supply of the nation; and that the public interest demands that the farmer be encouraged to attain a superior and more direct system of marketing in the substitution of merchandising for the blind, unscientific and speculative selling of crops; and that for this purpose, the farmers should secure special guidance and instructive data from the Dean of the College of Agriculture of the University of Kentucky."

Within a period of five years, Cooperative Marketing Acts generally similar to the Kentucky or Texas Cooperative Marketing Acts have been adopted, with certain variations, in over forty states of the Union:

Alabama: Laws of Alabama Special Session 1921, No. 31, approved Oct. 29, 1921.

Arizona: Session Laws of Arizona 1921, Chapter 156, approved March $22,1921$.

Arkansas: General Acts of Arkansas, 1921, Act 116, approved Feb. 14, 1921.

Callfornia: Laws of California, 1923, Chapter 103, approved May 4, 1923 .

Colorado: Session Laws of Colorado, 1923, Chapter 142, approved March 30, 1923. 
Connecticut: Public Acts of Connecticut, 1923, Chapter 251, approved June 1. 1923. (Contract and enforcement clauses; protective provisions).

Florida: Laws of Florida, 1923, Chapter 9300, approved June 7, 1923.

Georgia: Laws of Georgia, 1921, No. 279, approved Aug. 15, 1921.

Idaho: Session Laws of Idaho, 1921, Chapter 124, approved Feb. $25,1921$.

Illinois: Laws of Ilinois, 1923, p. 286 (Senate Bill 165) (Smith Hurd 111. Revised Statutes, Chapter 32, Sections 440-472), approved June 21, 1923.

Indiana: General Laws of Indiana, Acts of 1925, Chapter 20, approved Feb. 231925.

Iowa: Laws of Iowa, 1921 (41), G. A. Chapter 122, approved April 5, 1921 (enforcement clauses only).

Kansas: Laws of Kansas, 1921, Chapter 148, approved March 21, 1921.

Kentucky: Acts of Kentucky, 1922, Chapter 1, approved Jan. 10, 1922.

Louisiana: Acts of Louisiana, 1922, Act No. 57 approved July $13,1922$.

Manne: Public Laws of Maine, 1923, Chapter 88, approved March 24, 1923.

Maryland: Laws of Maryland, 1922, Chapter 197 (Code oi Public General Laws of Maryland, Art. 23, Sections 469 to 496), approved April 13, 1922.

Massachusetts: Acts of Massachusetts, 1323, Chapter 438, Section 4, approved May 23, 1923. (General Laws, Mass. Chap. 157, Sec. 1018. Not standard contract provisions; enforcement clauses; a Iew protective provisions).

Minnesota: Laws of Minnesota, 1923, Chapter 264, approved April 16, 1923.

Mississippi: Laws of Mississippi, 1922, Chapter 179, approved March $28,1922$.

Missouri: Laws of Missouri, 1923 (C. S. H. B. 439), page 111, approved April 9, 1923.

Montana: Laws of Montana, 1921, Chapter 233, approved March 5, 1921.

Nebraska: Session Laws of Nebraska, 1925, Chapter 79, approved March 13, 1925.

Nevada: Statutes of Nevada, Chapter 236, approved March 23, 1921.

New Hampshire: Laws of New Hampshire, 1925, Chapter 33, approved March 19, 1925.

New Jersey: Laws of New Jersey, 1924, Chapter 12, approved Feb. $28,1924$.

New Mexico: Laws of New Mexico, 1925, Chapter 99, approved March 17, 1925.

New York: Laws of New York, 1924, Chapter 616, approved May $5,1924$. 
North Carolina: Public Session Laws of North Carolina, 1921, Chapter 89, approved March 7, 1921.

North Dakota: Session Laws of North Dakota, 1921, Chapter 44, approved March 10, 1921.

Uhio: Laws of Ohio, 1923, Page 91, approved April 13, 1923. Ohio G. C., Sections 10186-1 to 30 .

Uklahoma: Session Laws of Oklahoma, 1923, Chapter 181, approvei March 19, 1923.

Oregon: Laws of Oregon, 1915, Chapter 226; 1917, Chapter 411; 1921, Chapter 490.

South Carolina: Acts of South Carolina, 1921, No. 203, approver March 29, 1921.

South Dakota: Laws of South Dakota, 1923, Chapter 15, approved F'eb. 27, 1923.

'l'epnessee: Public Acts of Tennessee, 1923, Chapter 100, approved March 31, 1923.

Texas: General Laws of Texas, 1921, Chapter 22, approved March 1, 1921 .

Utah: Laws of Utah, 1923, Chapter 6, approved Feb. 8, 1923.

Virginia: Acts of Assembly of Virginia, 1922, Chapter 48 , approved Feb. 18, 1922.

Wasnington: Session Laws of Washington, 1921, Chapter 115, approved March 18, 1921.

West Virginia: Acts of West Virginia, 1923, Chapter 53, approved May 2, 1923.

Wisconsin: Wisconsin Statutes, 1921, Section 1786, e1-17a (contract clauses; ēforcement clauses; many protective provisions).

Wyoming: Session Laws of Wyoming, 1923, Chapter 83, approved March 1, 1923.

This Act has established the primary legal principles of Cooperative Marketing. We now have a fairly clear idea of what a cooperative may do; how it may enforce its contracts; how it may protect itself from unfair commercial war.

We know the limitations of cooperatives-that they cannot in many states, handle a pound of produce for a non-member and in certain others, may handle for non-members any amount equal to the aggregate amounts delivered by their members. Each member has one vote and democratic control is enforced by law. Annual reports are compulsory and some opportunity is afforded to check the cooperative management as to efficiency.

But primarily, the trend of law was set and a public policy clearly announced.

This type of law has been upheld in many jurisdictions, the most important decisions being: 
Kentūcky-Potter vs. Dark Tobacco Growers' Coop. Assn. (1923) 201 Ky. 441,257 S. W. 33.

Indiana-Burley Tobacco Growers' Coop. Assn. vs. Rogers (1926) 150 N. E. 384.

Dark 'Tobacco Growers' Coop. Assn. vs. Robertson (1926) 150 N. E. 106.

Unfo-List vs. Burley Tobacco Growers' Coop. Assn. (1926) 151 N. E. 471.

Tennessee-Dark Tobacco Growers' Coop. Assn. vs. Dunn (1924) 266 S. W. 308.

Dark Tobacco Growers' Coop. Assn. vs. Mason (1924) 263 S. W. 60 .

Alabama-Farren vs. Alabama Farm Bureau Cotton Assn. (1925) 104 So. 264.

Colorado-Rifle Potato Growers' Coop. Assn. vs. Smith. (1925) 240 P. 397.

Georgia-Harrell vs. Cane Growers' Coop. Assn. (1925) 126 S. E. 531. Kansas-Kansas Wheat Growers' Assn. vS. Schulte (1923) 216 P. 311. Louisiana-Louisiana Farm Bureau Cotton Growers' Assn. vs. Clark (1926) 107 So. 115.

Minnesota-Minnesota Wheat Growers' Cooperative Marketing Assn. vs. Huggins (1925) 203 N. W. 420.

Mississippi-Brown vs. Staple Cotton Coop. Assn. (1923) 96 So. 849.

Nebraska-Nebraska "Wheat Growers' Assn. vs. Norquest (1925) 204 N. W. 798.

North Carolina-Tobacco Growers' Cooperative Assn. vs. Jones (1923) 117 S. E. 174.

Texas-Texas Farm Bureau Cotton Assn. v. Stovall (1923) 253 S. W. 1101.

It has been held constitutional in every instance, except in the Clark case where the Act generally was held valid but one clause, providing for a conclusive presumption that the landlord controls the products raised on his farm, was held unconstitutional; and in one Minnesota case, Minnesota Wheat Growers' Assn. v. Radke, (1925) 204 N. W. 314, where only the protective provision against dealers or warehousemen, who try to persuade or permit members to breach their contracts by sales to them, was declared unconstitutional.

$\Delta$ s a matter of special local interest, the Kentucky Court of Appeals directly upheld both of these provisions-Feagaini $\nabla$. Dark Tobacco Grower's' Coop. Assn. (1924) 261 S. W. 607 and (a) Dark Tobacco Growers' Coop. Assn. v. Daniels (1926) 284 S. W. 399 ; (b) Liberty Warehouse Co. v. Burley Tobacco Growers' Cooperative Assn. (1925) 271 S. W. 695. 
The same Court of Appeals, in a well-reasoned decision, Burley Tobacco Growers' Cooperative Assn. v. City of Carrollton, Ky., (1925) $270 \mathrm{~S}$. W. 749 , declared invalid the tax exemption contained in Section 31 of the Kentucky Act. This provision was unique; and differed from the usual tax-exemption clause found in the standard act.

Nowhere else has that exemption been disturbed.

Thus the basic law seems ta be established. A new public policy has been proclaimed and has been universally followed.

In the Potter case, $257 \mathrm{~S}$. W. 33, the Kentucky Court of A.ppeals recognized, with breadth of vision and telling force, the effect on law of the new economic development; and we quote at pardonable length:

"rhe basis of this change in public opinion toward combination and ciassification is not in any sense political, but economic rather, and, in our judgment, it is because of basic economic conditions, affecting vitally not only the farmers, but also the public weal, that the classification based upon agricultural pursuits is reasonable, just, and imperative for the good of the entire nation and every citizen thereof, If this be true, the Bingham Act is based upon a classification that is not offensive to the equal protection provisions of the Fourteenth Amenament.

'l'he fact that other productive groups can, do, and for many years have marketed their wares as groups, and not as individuals, and that they are and have been enabled through group organization or 'gentlemen agreements' to regulate the distribution and stabilize the prices of their products, is a fact known of all men which can neither be denied nor blinked by the courts; as is also the fact that farmers, it unorganized, necessarily act as individuals and not as groups in marketing their products, resulting in 'dumping' by the farmers, distribution by speculators, and unconscionable and uneconomic spread between producer and consumer in the necessities of life and an inevitable demoralization of basic economic conditions to the hurt directly or indirectly of every citizen.

With a clear recognition of this fact borne in upon the public conscience by the threatened economic collapse of the farming industry indispensable to public welfare and national stability, if not national existence, an enlightened public opinion unmistakenly demands that farmers be permitted to organize for the marketing of their crops, not merely for their own protection, but for the public good. But what has current public opinion with reference to economic questions to do with constitutional inhibitions and guaranties? Just this: It often, as here, affords the proper and usual approach for a consideration of their terms and meaning. 
That all law, even constitutional law, it not static, but progressive, and in step always with sound economic conditions and an enlightened public policy, recently has come to be realized clearly, if ever it may have been thought otherwise, as is attested by highest judicial and lay utterances.

The best evidence of the sure foundation of the federal Constitution is not that it was deciaratory of the highest conceptions of truth and justice with reference to community life when it was written, but that, correctly interpreted, it is equally so today, despite the many changes time and experience have brought in such conceptions. The constitution in the Fourteenth Amendment declared the public policy of equal protection of the laws, unalterably, both then and now, it is true, except by formal amendment, but. being written for time rather than a day, most wisely left it to the Legislatures and the courts to provide the means and define the terms in accordance with an enlightened public consciousness which continually strives toward, and constantly attains, if but slowly and haltingly, a better understanding of community life. Unquestionably, as that complex problem is understood by the best thought of today, the Bingham. Act, by enabling the farmers to market their crops cooperatively for tine purpose, as declared in the act of regulating distribution and stablizing the prices of farm products, serves a pressing public need that justifies the classification of farmers as a distinct class, and treats all of the class equally and fairly, and not better, if that were important, than other distinct productive classes are treated under the laws of the state and nation. It does not, therefore, offend the equal protection provisions of the federal Constitution, notwithstanding the fact that 21 years ago the Supreme Court of the United States in the case of Connolly vs. Union Sewer Pipe Co. supra, indicated a somewhat contrary view, but which 1s, under the more recent decisions of that court, easily distinguished upon several grounds."

This view has been generally approved and frequently cited, and the Appellate Courts have almost universally given a liberal interpretation to all of the provisions of these Marketing Acts.

In addition to this standard act, there have been bits of auxiliary legislation tending to establish protection for the farmers in their cooperative or other activities, particularly in contact with warehousemen or crop lien holders.

For example, in Virginia and Kentucky, acts were passed to regulate warehousemen and to cause them to record and disclose the true names of the owners of tobacco sold upon their auction floors. These acts were attacked but held valid in Reaves Warehouse Corporation v. Commonwealth, Virginia 
(1925) 126 S. E. 87; Jewel Tobacco Warehouse Co. v. Kemper, Kentucky( 1925)2 68 S .W. 324.

In Maine, an elaborate statute was passed, to provide that the crops of growers, members of a cooperative marketing association, against which crop liens had been placed after the grower had become a member of the Association and after the Association had duly recorded his name in the county as a member under such contractual obligations, must be delivered to the Association in accordance with the terms of the contract, and that the lien would then follow the proceeds due such member instead of following the products themselves.

This law, as such, has not yet been passed upon by any court of last resort.

Judicial opinion has been steadily upholding both the basic statute and the Associations organized thereunder and the contracts made by such Associations.

It was inevitable that much litigation would follow cooperative organization even under a standard law. First, there was a new relationship to be established toward the public. A new public policy was announced. The State became the encourager of Cooperation. The public generally was concerned, sometimes as consumers, sometimes as creditors, sometimes as dealers, always as citizens.

Wverywhere the cooperatives have been held in line with the best public policy.

Only once has any state official openly attacked a cooperative in points involving public policy.

The Attorney General of Tennessee started an action described as follows in an opinion, State of Tennessee ex rel Thompson v. Burley Tobacco Growers' Coop. Assn., Court of Appeals, Tenn., 1926:

"The bill in this cause was brought by the State of Tennessee, on relation of its Attorney General, under Section 3188 of Shannon's Annotated Code, against the Burley Tobacco Growers' Cooperative Assnciation, a corporation chartered under and by virtue of the Bingham Cooperative Marketing Act of Kentucky (Acts of Kentucky, 1922, Chapter 1), for the purpose of inhibiting it from transacting its business in Tennessee upon the ground that the business in which it is engaged and which it proposed to transact, constitutes it an unlawful trust and combination, violative of the provisions of the anti-trust statutes of Tennessee compiled in Section 3185 of Shannon's Annotated 
Code. At the time of the filing of the bill the Chancellor granted a preliminary injunction upon ex parte application. Several motions were made to dissolve this injunction but this was denied; except that the Association was permitted to perform all contracts made by It with farmers in Tennessee prior to the issuance of the injunction and to use, as incident thereto, any warehouse owned or to be built by it, to buy or rent other warehouses such as it might deem proper for storing, handling and selling tobacco purchased by it or to be received by it under contracts made by it prior to the issuance of the injunction.

Upon the hearing, upon a voluminous record, the Chancellor sustained the bill, holding that the defendant Association was an unlawful combination in restraint of trade, existing and operating in violation of the anti-trust statutes, and, therefore he rendered a decree perpetually enjoining said defendant from doing business in Tennessee. From this decree the Association, and certain of its officers and agents, who were made co-defendants, have appealed."

\section{The final conclusion of this Court of Appeals was:}

"In the last analysis this controversy turns upon the question of jublic policy. While the police powers of the state may be exerted under the statutes, with reference to economic problems, there is much danger of transcending the power thus given, in order to interfere with contractual relations and situations of a purely business character. Whether the cooperative marketing system is or not economically beneficial is not primarily a judicial question. As an economic question it may be dealt with governmentally by the legislative department. The legislature has manifestly treated as a farored class, persons engaged in agriculture, as they are so widely scattered and compose so numerous a class that it is a physical and enconomic impossibility to combine them all in any commercial enterprise. Many of them are very small producers of such limited means that they must market their products immediately after harvesting and are therefore at the mercy of purchasers without any voice whatever in making prices or terms. Merchants and manufacturers are not of such character nor are they so situated. Recognizing the apparent necessity of cooperative marketing of farm products, the legislatures of at least two-thirds of the states and the Congress of the United states have enacted statutes legalizing the system, and not only have these statutes been held constitutional, but the standard marketing contracts made by Associations with their members have been held valid and enforceable in a long line of cases so numerous that we will not undertake to cite them. Most of them will be found in the Notes in 25 A. L. R. p. 1090, and 33 A. L. R. p. 247. Later cases, in addition to those already cited herein, are: Burley Tobacco Growers' Cooperative Association vs. Rogers (Ind.) 150 N. F. 384; Dark 
Tobacco Growers' Cooperative Association vs. Robertson (Ind.) 150 N. E. 106; Rifle Potato Growers' Association vs. Smith (Colo.) 240 rac. 937.

Upon a careful consideration of all of the facts presented in the large record in this case, we are unable to agree with the conclusions of law or fact reached by the Chancellor as grounds for sustainingl the bill in this cause. We do not think that the Association in question has practiced unreasonable restraint of trade, fraudulent rivalry or coercion, illegal suppression of competition, undue limitation of production, impairment of quality, decreasing, wages or prices of materials; or that it is manifest that such will be the probable effect of the operation of the Association.

The evidence in the case before us fails, in our opinion, to meet the requirements set forth in the foregoing rules. These requirements are applicable to a proceeding to deprive a foreign corporation, duly licensed, from further doing business within the State of Tennessee.

We have disposed of this case with the greatest respect for the late Attorney General, for his learning, ability, zeal and his sincere motives in instituting this proceeding; but we are unable to hold upon this record that this asscciation should be inhibited from further carrying on a system of cooperative marketing of Burley tobacco. Whatever may be the practices of the Association in the future, neither it nor the Tennessee farmers favorable to it have, in our opinion, become subject to be deprived of its right to do business in Tennessee. The decree of the Chancellor is reversed, the injunction is dissolved and the biil is dismissed. The costs are adjudged against the State. The Clerk will certify the bill of costs to the Comptroller for payment."

The only other instance, within my knowledge, where an Attorney General directly attacked a cooperative association, was in California where an action was very properly brought against a Dairy Cooperative to inquire, under quo warranto proceedings, why it was using its funds to go into the ice business without particular authority in its charter.

Other than this Tennessee experience, there are no attacks on the Cooperatives from the standpoint of policy, except where they arise incidentally as part of the conflict with speculative dealers or as a desperate defense urged by some grower who seeks to evade the obligation of his own contract. All the recent decisions, particularly the List case (Ohio), Rogers and Robertson cases (Indiana), Dunn and Mason cases (Tennessee), Potter case (Kentucky), all cited above, are of one accord in approval of the new public policy. Several of these cases, notably the 
List, Potter and Dunn cases, go specifically into the famous Connolly case (Connolly v. Union Sewer Pipe Co. 22 U. S. Sup. Ct. 431), the standby of those who argue for the old public policy and the old refusal to permit classification of the farmers as a group separate and distinct from other industrial groups in a legal sense.

Besides this public relationship the Cooperatives have had to work out their relations with their members.

The modern commodity cooperatives bear a dual relationship here. The grower is a member; and as a member he has certain rights, such as voting, and certain specific obligations.

Separately, he is a contract-party with the Association on his marketing agreement. He coud not, in some states, become a contract-party without first being a member; but in every instance, the relationships are separate. He may cease to be a contract-party when the term of his agreement expires; but he does not thereby cease to be a member.

He may no longer have to deliver his cotton or his tobacco; but he may have the right to vote for directors, unless and until he withdraws or is dropped from membership.

$\mathrm{He}$ may have a financial interest in the Association by reason of his right in the membership fund; or perhaps by his rights in the reserve. But even here, we must distinguish, because his rights in the reserve are rights as a contract-party, arising out of deductions from the gross proceeds of the sale of products under his marketing contracts.

On these problems, the law is being made very slowly. But it is being made with great definiteness on his rights or obligations as a contract-party.

There are various kinds of cooperative contracts-some set out solely in by-laws, which is an undesirable and awkward type of contract; some in separate documents executed with a recognition that rights as a contract-party are separate from rights as a member.

These contracts may be firm for a term of years, as the Burley Tobacco contracts; or a long term, firm for one or two years but with a right of withdrawal thereafter annually; or one year contracts to be renewed annually by signature; or term or perpetually self-renewing contracts, presumed to be 
renewed each Jear, unless notice to the contrary is given by a certain date.

These contracts may be agency contracts or contracts in which title passes to the cooperative. In the latter class, the favorite type is the sale and re-sale contract, in which no definite sale-price is named but a definite method for ascertaining price is set forth.

There is no space here to analyze the decisions on these various types of contracts. It will suffice to state that the cooperative contracts are now almost universally upheld, both from the statutory authority and from a common-law basis, as the Potter case indicates.

In Iowa, the effect of the old Reeves and Iudowese cases has been swept away by the recognition of a new public policy in Clear Lake Coop. Assn. v. Weir, Iowa 1925, 206 N. W. 297. In Colorado, the decision of Burns v. Wray has becone ancient law in view of the Rifle ease.

There are slight differences between courts; but, as a whole, the decisions have made enforcement of cooperative contracts relatively easy througheut the land.

Certain cases, such as the Stovall case in Texas, Brown case in Mississippi, Jones case in North Casolina, Robertson case in Indiana, are exceedingly interesting for their statements on the technical problems in contracts.

They can be read profitably for their discussions and their approval of the remedies set out in the statutes, both legal and equitable.

On the other hand, there is a decision in Oklahoma, Oklahoma Cotton Growers' v. Salyer, Okla. 1925, 243 p. 232, which not only denies relief on the marketing contract under a peculiar set of facts but also sets up a decision on liquidated damages, which seems to run contrary to the logic of all courts in the Inited States or in Canda that have passed on this issue in Cooperative cases. I here also suggest that scholars will find much interest in the discussions on public policy, restraint of trade, liquidated damages in the case of Saskatchewan Coop. Wheat Producers Ltd. v. Zurowski (1926) 3 D. L. R. 810, in which the famous Canadian wheat pools modeled after our own commodity associations, maintained its standard contract in the highest court in Saskatchewan, particularly on the liquidated 
damage clause which was written by the same hand and in substantially the same terms as the Burley Tobacco contract enforcement clause.

There are still some differences between the courts as to enforcement of contracts against tenants with notice; as against transfers to wives or sons; as against bankers or others holding crop mortgages.

In these problems, the courts of Kentucky, Kansas and Texas have been most effective in aiding the cooperatives to maintain the integrity and priority of their contracts as against all manner of attempted conveyances or subordination of rights. The Kansas Wheat Growers' Association decisions are cited as the leading decisions, where bank mortgages are concerned; the Texas Cotton Association decisions share with the Kentucky groups the distinction of being cited most often as to rights or obligations of landlords.

One of the most recent expressions of law in this connection is the case of Dark Tobacco Growers' Cooperative Association v. Daniels (Ky. 1926), 284 S. W. 399, in, which the court declares :

"lhe landlord could rent or lease his land and could thus control the sale and delivery of crops, and had the power by stipulation to Ieserve to himself the right to have tobacco or any other crop produced on his land sold or delivered upon a certain market or to a certain person or association. The marketing agreement and Bingham Act must be construed as a part of every rental contract or lease of lands for the purpose of raising farm products which the member makes with reference to land owned by him or in which he has an interest or over which he has control. In every such instance he has the legal right to exercise control over the crops. The spirit and substance of the Bingham Act and marketing agreement signed by the member requires him to exercise control over his lands to the extent of seeing that all tobacco raised thereon is marketed according to his agreement. A failure to exercise such control in the manner inüicated is a violation of his agreement."

Of further interest is the Coyle case, Coyle v. Dark Tobacco Growers' Cooperative Association, Ky. 1925, 277 S. W. 318, which holds, as the head-note states:

"In suit to enjoin sale of tobacco to others than cooperative tobacco association and for aamages, evidence held to show that convejances by husband to wife and son, though for valuable consideration, were 
fraudulent and roid as to complainant in view of $\mathrm{Ky}$. St. 1906, being made for the fraudulent purpose of enabling husband to avoid contracts made with association, of which contract and fraudulent intention wife and son had knowledge."

These cases are referred to because they show the general tendency of the courts of Kentucky to enable the Cooperativo to carry out its contracts and to broaden out the law along the general lines indicated by the Legislature.

It would be interesting to discuss here the nature of cooperative contracts; the defenses urged to prevent enforcement thereof; the attacks on the statutory provisions permitting various kinds of relief and the protective sections directed against dealers and others who induce or permit breaches of contract.

But these problems would necessitate and deserve separate consideration in a separate article.

I have here simply attempted to set out that there is a distinct trend of law affecting cooperative marketing associations, built around a recognition of a new economic development. This law is expressed primarily in certain standard statutes, interpreted and broadened by court decisions of many states.

A definite public policy has been announced by the legislatures and extended by the courts. This is shown in the long series of decisions cited above and in many other cases involving enforcement of contracts.

In the space of five years, the legislatures and courts have made greater progress in clarifying the rights, powers and obligations of cooperatives and their members than was accomplished in the first generation of ordinary corporation development.

This is a tribute to the great importance attached to rural problems at this time; and also to the hope that in cooperative marketing may be found a partial solution of the difficulties that beset the farmer.

The legislatures and the courts have let in the light. On every important issue today connected with' cooperative marketing, the law is clear and can be found established in the decisions of courts of highest repute among the appellate courts of our land. 
The unsettled problems are minor. Many will be determined by legislative action. Many will be determined by preponderance of decisions and by local law traditions.

But in the general story of the development of cooperative marketing law, Kentucky will always stand at the very front, by reason of its model statute, its cogent and widely-cited decisions and its world-famous example of commodity cooperation, the Burley Tobacco Growers' Cooperative Association.

Chicago, III.

Aaron SAPIRo. 